\title{
Bis-epoxyethyl derivatives of distamycin A modified on the amidino moiety: Induction of production of fetal hemoglobin in human erythroid precursor cells
}

\author{
NICOLETTA BIANCHI ${ }^{1}$, MONICA BORGATTI ${ }^{1}$, EITAN FIBACH ${ }^{2}$, EUGENIA PRUS ${ }^{2}$, \\ CRISTINA ZUCCATO ${ }^{1}$, GIULIA BREVEGLIERI ${ }^{1}$, PIER GIOVANNI BARALDI ${ }^{3}$, \\ ROMEO ROMAGNOLI ${ }^{3}$ and ROBERTO GAMBARI ${ }^{1,4}$ \\ ${ }^{1}$ BioPharmaNet, Dipartimento di Biochimica e Biologia Molecolare, Università di Ferrara, Ferrara, Italy; \\ ${ }^{2}$ Hadassah University Hospital Ein-Kerem, Jerusalem, Israel; ${ }^{3}$ Dipartimento di Scienze Farmaceutiche, \\ Università di Ferrara; ${ }^{4}$ Laboratory for the Development of Pharmacological and Pharmacogenomic \\ Therapy of Thalassemia, Biotechnology Center, Ferrara University, Ferrara, Italy
}

Received July 9, 2008; Accepted August 30, 2008

DOI: 10.3892/ijmm_00000107

\begin{abstract}
Derivatives of distamycin A modified at the Cterminal amidine moiety and tethered to bis-epoxyethyl moieties at the $\mathrm{N}$-terminal position were tested for their ability to induce erythroid differentiation in the human erythroleukemic cell line K562. None of the compounds without bis-epoxyethyl moiety were active. A comparison of the biological activity of diepoxy compounds containing different non-basic amidine-modified moieties, showed low activity of amidoxime, carbamoyl and $\mathrm{N}$-methyl carbamoyl derivatives as differentiation agents. In contrast, a cyanamidine derivative, compound 3, was able to induce erythroid differentiation of K562 cells. In addition, the cyanamidine derivative 3 was able to induce $\mathrm{HbF}$ accumulation following treatment of cultures of erythroid precursor cells isolated from the peripheral blood of normal subjects.
\end{abstract}

\section{Introduction}

The identification and characterization of potential therapeutic agents for the treatment of $\beta$-thalassemia and sickle cell anemia is based on the pharmacologically mediated regulation of the expression of human $\gamma$-globin genes (1-8) It is well established that an increased production of fetal

Correspondence to: Professor Roberto Gambari, Department of Biochemistry and Molecular Biology, University of Ferrara, Via Fossato di Mortara n.74, 44100 Ferrara, Italy

E-mail: gam@unife.it

Abbreviations: rt, room temperature; $\mathrm{HbF}$, fetal hemoglobin; HPLC, high pressure liquid chromatography

Key words: distamycin analog, erythroid differentiation, $\gamma$-globin, fetal hemoglobin, B-thalassemia hemoglobin $\left(\mathrm{HbF}, \alpha_{2} \gamma_{2}\right)$ leads to a significant improvement of the clinical status of the patients $(4,5,7)$. Therefore, many published experiments were designed to find hormones, cytotoxic agents, hemopoietic cytokines and short fatty acids as agents able to increase $\mathrm{HbF}$ levels in humans (1-3,9-11).

In this respect, DNA-binding drugs are very interesting, since we reported that mithramycin, cis-platinum and tallimustine analogs are potent inducers of erythroid differentiation (12-14). The same compounds have been demonstrated to increase $\mathrm{HbF}$ production in human erythroid precursor cells obtained from peripheral blood of normal subjects and thalassemic patients (9). In particular, we found that the distamycin analog tallimustine and some related compounds are powerful inducers of differentiation and $\gamma$-globin mRNA accumulation in normal human erythroid progenitors (10).

In this study, we report on the biological characterization of potential HbF inducers of the hybrid molecules 3-6 that include the amidine-modified tripeptide tris-N-methyl-pyrrolecarboxamide distamycin A, which contains two electrophile epoxydic functions on the amino end. In the bis-epoxyethyldistamycin A hybrids, the amidino moiety has been replaced by various non-basic groups of a different electronic nature, lipophilicity and bulk, such as cyanamidine (compound 3), amidoxime (compound 4), carbamoyl (compound 5) and Nmethyl carbamoyl (compound 6).

As was previously reported, the synthesis of amidinomodified analogs provides a number of advantages (15-18). First, they are not hygroscopic and are easy to handle. Moreover, these derivatives are uncharged. Thus, products and intermediates can be readily purified by column chromatography and recrystallized.

These compounds were investigated for potential erythrodifferentiation ability, in order to verify whether some of them were able to increase $\gamma$-globin gene expression. We initially analysed erythroid differentiation by benzidine $/ \mathrm{H}_{2} \mathrm{O}_{2}$ assay and Northern blotting using the human leukemia K562 cell line as a cellular model $(19,20)$. We then analyzed $\mathrm{HbF}$ production after in vitro treatment with the most potent 
compound in erythroid precursor cells using the two-phase liquid culture procedure $(21,22)$. This methodology can be used to identify compounds stimulating $\mathrm{HbF}$ accumulation in erythroid progenitors obtained from normal donors as well as subjects with hematological disorders (9).

\section{Materials and methods}

Chemistry. Reactions were carried out under an inert atmosphere of dry nitrogen, unless otherwise described. Standard hypodermic syringe techniques were applied for transferring dry solvents. Starting materials were purchased from Fluka and were used without purification. Reaction courses and product mixtures were routinely monitored by TLC on silica gel (precoated $\mathrm{F}_{254}$ Macherey-Nagel plates) and visualized with aqueous $\mathrm{KMnO}_{4}$. Chemical shifts ( $\delta$ ) are given in the ppm upfield from tetramethylsilane. Melting points (mp) were determined on a Büchi B540 apparatus and are not corrected. The products reported showed ${ }^{1} \mathrm{H}-\mathrm{NMR}$ spectra in agreement with the assigned structures. ${ }^{1} \mathrm{H}-\mathrm{NMR}$ was determined in $\mathrm{CDCl}_{3} / \mathrm{DMSO}$ solution with a Bruker AC200 spectrometer. Organic solutions were dried over anhydrous $\mathrm{Na}_{2} \mathrm{SO}_{4}$. Dry DMF was distilled from calcium chloride and stored over molecular sieves ( $3 \AA$ ). Reaction solvents, recrystallization and work-up solvents were used as received. The synthesis of compounds studied herein has been described in detail elsewhere. The compounds included 3: $\mathrm{N}-[5-(\{[5-$ (\{[(3-amino-3-(cyanoimino)propyl]amino $\}$ carbonyl)-1methyl-1H-pyrrol-3-yl]amino carbonyl)-1-methyl-1Hpyrrol-3-yl]-4-bis(oxiranyl)amino-1-methyl-1H-pyrrole-2carboxamide; 4: N-[5-(\{[5-(\{[(3-amino-3-(hydroxyimino) propyl]amino carbonyl)-1-methyl-1 H-pyrrol-3-yl] amino\}carbonyl)-1-methyl-1H-pyrrol-3-yl]-4-bis(oxiranyl) amino-1-methyl-1H-pyrrole-2-carboxamide; 5: N-[5-(\{[5(\{[(3-amino-3-(carbamoyl)ethyl $]$ amino $\}$ carbonyl)-1-methyl1H-pyrrol-3-yl]amino carbonyl)-1-methyl-1H-pyrrol-3-yl]4-bis(oxiranyl)amino-1-methyl-1H-pyrrole-2-carboxamide; and 6: N-[5-(\{[5-(\{[(3-amino-3-(N-methylcarbamoyl)ethyl] amino carbonyl)-1-methyl-1H-pyrrol-3-yl]amino \} carbonyl)1-methyl-1H-pyrrol-3-yl]-4-bis(oxiranyl)amino-1-methyl1H-pyrrole-2-carboxamide.

Molecules used in the biological assays. Distamycin A, compounds 3-6 and 11-14 were dissolved in dimethyl sulfoxide (DMSO) at $1 \mathrm{mg} / \mathrm{ml}$, aliquoted and stored in the dark at $-20^{\circ} \mathrm{C}$. The bis-epoxyethyl-distamycin A derivatives were diluted in medium immediately before use. Tallimustine was purchased from Sigma/Aldrich (Milwaukee, WI, USA). Known inducers of K562 differentiation (hydroxyurea, mithramycin, butyric acid, tallimustine and cisplatin) were employed as positive control compounds $(9,13,23)$. These molecules were purchased from Sigma/Aldrich.

K562 cells and cell culture conditions. The human chronic myelogenous K562 cell line (19) was obtained from the American Type Culture Collection (ATCC, Rockville, MD) and grown in vitro in RPMI-1640 medium (Sigma/Aldrich), supplemented with $10 \%$ fetal bovine serum (FBS) (Celbio, Milan, Italy), $2 \mathrm{mM}$ L-glutamine (Sigma/Aldrich), a solution of $50 \mathrm{U} / \mathrm{ml}$ penicillin and $50 \mu \mathrm{g} / \mathrm{ml}$ streptomycin (Sigma/
Aldrich) in a humidified atmosphere of $5 \% \mathrm{CO}_{2} /$ air at $37^{\circ} \mathrm{C}$ (20). K562 cells were usually seeded at 30,000 cells $/ \mathrm{ml}$ and then treatment with bis-epoxyethyl-distamycin A derivatives was carried out by adding the appropriate drug concentrations at the beginning of the cultures. The medium was not changed during the induction period. To determine the antiproliferative activity of these compounds, exponentially growing cells were continuously exposed to various concentrations of drugs for $72 \mathrm{~h}$ and cell growth was studied by determining the cell number/ml using a ZF Coulter Counter (Coulter Electronics, Hialeah, FL, USA) (14). Results were expressed as $\mathrm{IC}_{50}$ (dose causing 50\% inhibition of cell growth in treated cultures relative to untreated controls). Experiments were repeated at least twice. For each drug concentration, duplicate cultures were used. Vehicle or solvent controls were run with each experiment. To determine the effects of distamycin A, tallimustine and hybrid compounds 3-6 erythroid differentiation was calculated after 4-6 days of cellular culture by counting the proportion of benzidine-positive cells with a solution containing $0.2 \%$ benzidine in $5 \mathrm{M}$ glacial acetic acid and $10 \% \mathrm{H}_{2} \mathrm{O}_{2}$, as described elsewhere (24).

RNA isolation and Northern blotting. Total RNA was phenol-chloroform-extracted from the cytoplasm of treated and untreated K562 cells as described elsewhere (25). Solutions were made in diethylpyrocarbonate (DEPC)-treated water. The extracted RNA was aliquoted, precipitated in 2 volumes of absolute ethanol and stored at $-80^{\circ} \mathrm{C}$, washed once with cold $75 \%$ ethanol, dried and dissolved in DEPC-treated water before use. Total RNA $(10 \mu \mathrm{g})$ was loaded onto $1 \%$ agarose gel, electrophoresed, transferred to a nylon membrane (Gene Screen Plus) and hybridized using a ${ }^{32}$ P-labelled JW151 plasmid probe containing human $\gamma$-globin coding gene (26). The $\beta$-actin probe was produced by RT-PCR (reverse transcriptase polymerase chain reaction). K562 cells were treated with tallimustine at the final concentration of 50 and $100 \mathrm{nM}$ and with compound $\mathbf{3}$ at the final concentration of 25 and $50 \mu \mathrm{M}$. The $\gamma$-globin mRNA expression was evaluated after 5 days of cell growth and compared to the untreated K562 cells on the same day of culture as the seeding.

Human erythroid cell cultures from normal donors. The twophase liquid culture procedure was employed as previously described $(9,21,22)$. Mononuclear cells were isolated from the peripheral blood samples of normal donors by the FicollHypaque density gradient centrifugation and seeded in $\alpha$ minimal essential medium supplemented with $10 \%$ FBS (Celbio), $1 \mu \mathrm{g} / \mathrm{ml}$ cyclosporine A (Sandoz, Basel, Switzerland), and $10 \%$ conditioned medium from the 5637 bladder carcinoma cell line (27). The cultures were incubated at $37^{\circ} \mathrm{C}$, in an atmosphere of $5 \% \mathrm{CO}_{2}$ in air, with extra humidity. After a 7-day incubation in this phase I culture, the non-adherent cells were harvested, washed, and cultured in fresh medium composed of $\alpha$-medium, 30\% FBS, $1 \%$ deionized bovine serum albumin (BSA), $10^{-5} \mathrm{M}$ B-mercaptoethanol, $1.5 \mathrm{mM} \mathrm{L}$ glutamine, $10^{-6} \mathrm{M}$ dexamethasone, and $1 \mathrm{U} / \mathrm{ml}$ human recombinant Erythropoietin (EPO) (Inalco, Milan, Italy). This part of the culture is referred to as phase II (21).

Compounds were added on days 4-5 of phase II. Cell samples were analyzed on days 12 or 13 of phase II. Hemo- 

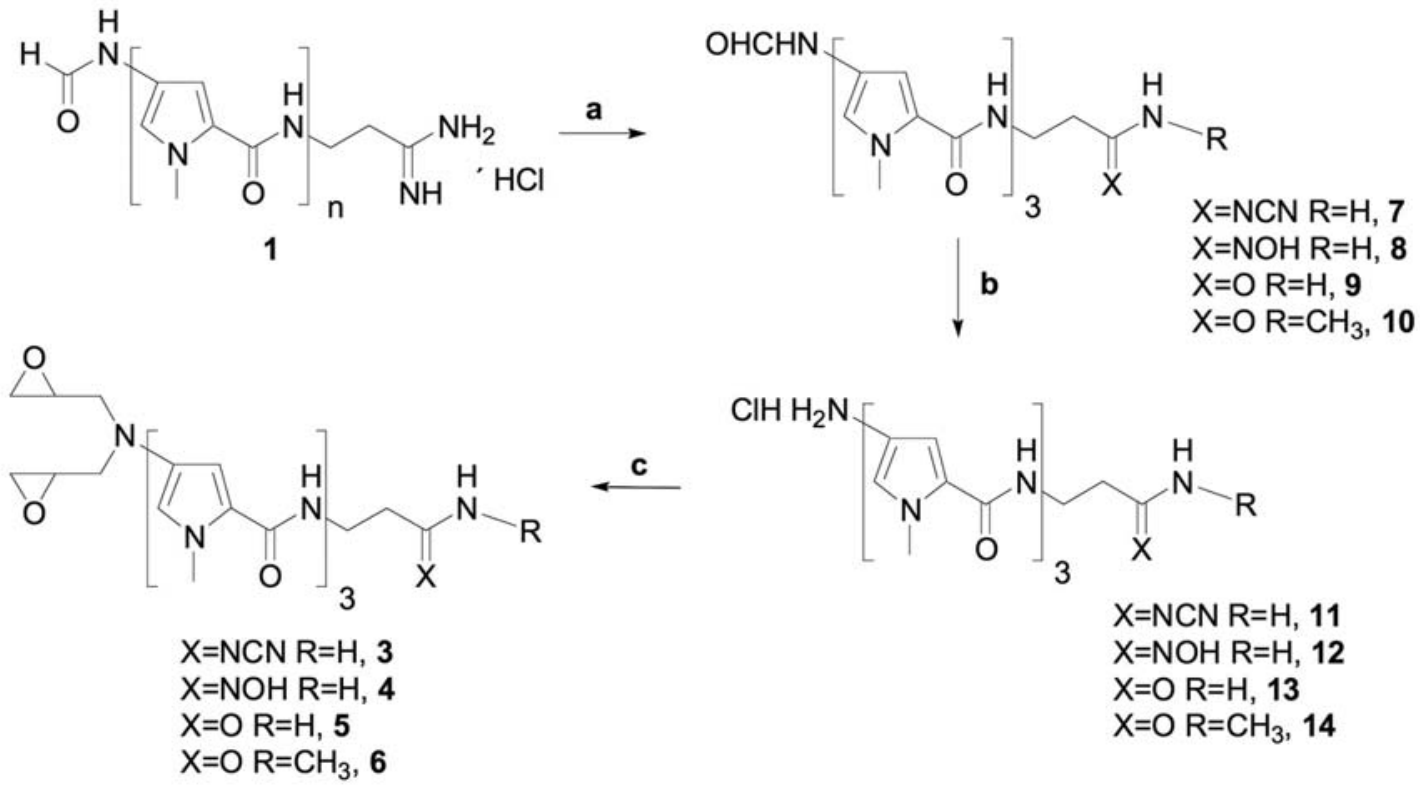

$\mathrm{X}=\mathrm{NCN} \mathrm{R}=\mathrm{H}, 11$

$\mathrm{X}=\mathrm{NOH} \mathrm{R}=\mathrm{H}, 12$

$\mathrm{X}=\mathrm{O} \mathrm{R}=\mathrm{H}, 13$

$\mathrm{X}=\mathrm{O} \mathrm{R}=\mathrm{CH}_{3}, 14$

Figure 1. Chemical structure and synthesis of the molecules employed in this study. The reagents are: a) $\mathrm{NH}_{2} \mathrm{CN}, \mathrm{NaH}_{1} \mathrm{DMF}$, rt (for the synthesis of 7); $\mathrm{NH}_{2} \mathrm{OH}, \mathrm{TEA}, \mathrm{DMF}, 70^{\circ} \mathrm{C}$ (for the synthesis of 8); $\mathrm{CH}_{3} \mathrm{NH}_{2}, \mathrm{DMF}, 80^{\circ} \mathrm{C}$ (for the synthesis of 9 and 10); b) $\mathrm{HCl}$ in EtOH, rt and c) epibromohydrin, TEA, $\mathrm{DMF}, \mathrm{rt}$.

globin-containing erythroid precursor cells were counted following staining by the benzidine $/ \mathrm{H}_{2} \mathrm{O}_{2}$ procedure (24). The proportion of $\mathrm{HbF}$ out of the total $\mathrm{Hb}(\%$ of $\mathrm{Hb}$ ) was determined by high-performance liquid chromatography (HPLC) as described elsewhere $(21,22)$.

High-performance liquid chromatography. Before HPLC analysis, cell samples were washed twice with sodium phosphate buffer, shaken and left for $30 \mathrm{~min}$ in ice. The cellular membrane was broken by centrifugation at 14,000 rpm and the supernatant was recovered. The HPLC analysis of hemoglobins was performed using Pharmacia LKB Gradient PUMP 2249, LKB VWM 2141 instrumentation at $415 \mathrm{~nm}$ and an ionic exchange column (Synchropak CM300 250x4.6 mm, Synchron Inc., Lafayette, IN). The flow ratio of samples was $0.8 \mathrm{ml} / \mathrm{min}$ in a mix of the two buffers [A] $\mathrm{CH}_{3} \mathrm{COONa} 0.3 \mathrm{M}$, Bis-Tris $30 \mathrm{mM}$, KCN $1.5 \mathrm{mM}$ in water solution and B) BisTris $30 \mathrm{mM}$, KCN $1.5 \mathrm{mM}$ in water solution] using a gradient elution. The standard curve was obtained by injection of different dilutions of commercial HbA purchased from Sigma/Aldrich and the $\mathrm{HbF}$ concentration of samples was calculated using a Spectra-Physics SP4600 integrator.

\section{Results}

Synthesis of bis-epoxyethyl distamycin hybrids. The synthesis of the bis-epoxyethyl distamycin hybrids 3-6 is summarized in Fig. 1. The starting material used for the synthesis of the cited compounds was distamycin A (1) (28). Cyanoamidine 7 was prepared from distamycin A with 3 equivalents of $\mathrm{NH}_{2} \mathrm{CN}$ sodium salt, obtained in situ with $\mathrm{NaH}(50 \%$ suspension in mineral oil) in DMF. Amidoxime 8 was prepared from 1 and 3 equivalents of $\mathrm{NH}_{2} \mathrm{OH}$-free base, obtained in situ from $\mathrm{NH}_{2} \mathrm{OH} \mathrm{HCl}$ and TEA, in DMF at $70^{\circ} \mathrm{C}$. Carbamoyl and $\mathrm{N}$-methyl carbamoyl derivatives $\mathbf{9}$ and $\mathbf{1 0}$, respectively, were prepared by reacting distamycin $\mathrm{A}(1)$, dissolved in $\mathrm{DMF}$, with 3 equivalents of aqueous $\mathrm{CH}_{3} \mathrm{NH}_{2}$ at $80^{\circ} \mathrm{C}$. The stallimycinmodified derivatives $\mathbf{7 - 1 0}$ were then transformed in the corresponding desformyl derivatives 11-14. The condensation of the amidino-modified deformyl distamycin A derivatives 11-14 with 1-bromo-2,3-epoxypropane (epibromohydrin) in DMF as solvent, in the presence of three equivalents of TEA as base, gave the bis-oxiranyl derivatives 3-6.

Evaluation of erythroid differentiation effects on K562 cell line after treatment with bis-epoxyethyl distamycin hybrids. The antiproliferative effects of the compounds employed in this study have been reported elsewhere (29). None of the compounds without bis-epoxyethyl moiety were active in inhibiting the proliferation of human K562 and murine L1210 leukemia cells. A comparison of the biological activity related to the diepoxy compounds 3-6 with different non-basic amidine-modified moieties, showed low activity for the carbamoyl and $\mathrm{N}$-methyl carbamoyl derivatives (compounds 5 and 6, respectively), moderate activity for the amidoxime analog $\mathbf{4}$ and good activity for the cyanamidine derivative $\mathbf{3}$.

To determine the effects on erythroid differentiation, K562 cells were treated with increasing concentrations of distamycin A (as a reference compound) and compounds 3-6 and erythroid differentiation were determined after 4-6 days of cellular culture by counting the proportion of benzidinepositive cells (24).

The results obtained and reported in Table I demonstrate that compound $\mathbf{3}$ displayed the highest effects on the induction of erythroid differentiation of K562 cells. Compounds 11-14, which lack the bis-epoxyethyl function, were unable to induce erythroid differentiation (data not shown). The ability of compound $\mathbf{3}$ to induce erythroid differentiation of the human leukemic K562 cells was compared to other differentiation agents. Notably, compound $\mathbf{3}$ is very active, and the level of 
Table I. Effects of distamycin A and hybrid compounds 3-6 on erythroid differentiation of human erythroleukemic K562 cells. ${ }^{a}$

\begin{tabular}{lcc}
\hline & \multicolumn{2}{c}{$\begin{array}{c}\text { Erythroid differentiation } \\
\text { (\% of benzidine-positive cells } \pm \mathrm{SD})\end{array}$} \\
\cline { 2 - 3 } Compound & \multicolumn{1}{c}{ Day 4} & Day 6 \\
\hline Distamycin A & $8.0 \pm 1.2$ & $20.0 \pm 2.2$ \\
$\mathbf{3}$ & $46.3 \pm 7.1$ & $65.3 \pm 6.2$ \\
$\mathbf{4}$ & $11.0 \pm 2.1$ & $13.0 \pm 3.5$ \\
$\mathbf{5}$ & $15.0 \pm 4.4$ & $16.0 \pm 4.8$ \\
$\mathbf{6}$ & $12.0 \pm 3.1$ & $15.0 \pm 4.6$ \\
\hline
\end{tabular}

${ }^{\mathrm{a}} \mathrm{K} 562$ cells were treated with concentrations of distamycin A and compounds 3-6 causing 50\% inhibition of cell proliferation. The proportion of benzidine-positive (hemoglobin-containing) cells was determined after 4 and 6 days of cell culture.

differentiation approaches that of the most potent erythroid inducers, such as cytosine arabinoside (ara-C) $(250 \mu \mathrm{M})(13)$, mithramycin (10 nM) (12), tallimustine (10 nM) (10) and cisplatin $(8 \mu \mathrm{M})(13)$. Compound $3(50 \mu \mathrm{M})$ is more active than butyric acid $(1.5 \mathrm{mM})$ and hydroxyurea $(\mathrm{HU})(120 \mu \mathrm{M})$ in increasing the proportion of benzidine-positive K562 cells. These data are summarized in Table II. The compounds were used at the indicated concentrations, which led to $50 \%$ inhibition of cell growth as reported elsewhere $(10,12,13)$.

Accumulation of $\gamma$-globin mRNA in human leukemic K562 cells treated with compound 3 . In order to determine whether the induction of erythroid differentiation of K562 cells is associated with a specific increase of $\gamma$-globin mRNA accumulation, total RNA was extracted from untreated K562 cells or K562 cells treated with tallimustine at the final concentrations of 50 and $100 \mathrm{nM}$ (14) or compound $\mathbf{3}$ at 25 and $50 \mu \mathrm{M}$ (experimental conditions close to the concentrations were found to cause $50 \%$ inhibition of cell proliferation). Tallimustine was used at concentrations much lower than those employed with compound $\mathbf{3}$, due to its strong antiproliferative and cytotoxic activity at the mM range (14). Northern blotting is shown in Fig. 2. As expected from previously published observations and from the data shown in Table I, distamycin was unable to induce an increase of $\gamma$-globin mRNA content, while tallimustine was able to stimulate the accumulation of $\gamma$-globin mRNA to an extent similar to ara-C (Fig. 2A). The results shown in Fig. 2B clearly indicate that erythroid differentiation induced by compound $\mathbf{3}$ after 5 days of treatment is associated with a sharp increase of $\gamma$-globin mRNA accumulation. The expression of $\beta$-actin mRNA was taken as an internal control and the ratio of specific $\gamma$-globin mRNA with respect to this reference sequence was calculated and shown in Fig. $2 \mathrm{C}$. The data suggest that compound $\mathbf{3}$ induces an increase of $\gamma$-globin mRNA accumulation in a specific manner and at a level similar to tallimustine induction. Fig. 2D and E shows an additional analysis performed using K562 cells after 3, 5 and
Table II. Effects of compound $\mathbf{3}$ on erythroid differentiation of human erythroleukemic K562 cells compared to powerful differentiation agents. ${ }^{\mathrm{a}}$

Erythroid differentiation

Compound (\% of benzidine-positive cells)

$\begin{array}{ll}\mathbf{3} & 68.2 \pm 4.1 \\ \text { Cytosine arabinoside } & 75.6 \pm 5.8 \\ \text { Mithramycin } & 72.9 \pm 1.9 \\ \text { Butyric acid } & 36.7 \pm 6.5 \\ \text { Hydroxyurea } & 28.2 \pm 3.7 \\ \text { Tallimustine } & 85.4 \pm 7.1 \\ \text { Cisplatin } & 75.4 \pm 6.6\end{array}$

${ }^{\mathrm{a}} \mathrm{K} 562$ cells were treated with concentrations of compound $\mathbf{3}$ causing $50 \%$ inhibition of cell proliferation. The results were compared to those obtained with the administration of optimal concentrations of potent inducers of erythroid differentiation. The proportion of benzidine-positive (hemoglobin-containing) cells was determined after 6 days of cell culture.

7 days of treatment with compound 3. The increase of $\gamma$ globin mRNA accumulation (Fig. 2E) is consistent with the results obtained after quantification of the proportion of benzidine-positive cells (Fig. 2D). The decrease of proportion of benzidine-positive cells after the 7-day induction is expected, due to a decrease of cell division efficiency of differentiated (benzidine-positive) versus non-differentiating (benzidine-negative) cells (10-14).

HbF production by administration of compound 3 on erythroid progenitor cells from peripheral blood. To study the effects of compound $\mathbf{3}$ on differentiation of the human erythroid progenitor cells we employed the two-phase liquid culture system as described elsewhere $(21,22)$. In this procedure, early erythroid committed progenitors (BFUe) derived from the peripheral blood proliferate and differentiate during phase I (in the absence of EPO) into late progenitors (CFUe). In phase II, in the presence of EPO, the latter cells continue their proliferation and mature into $\mathrm{Hb}$-containing orthochromatic normoblasts. Compound $\mathbf{3}$ was added at $200 \mu \mathrm{M}$ (a concentration found to cause $50 \%$ inhibition of cell growth) on days 4-5 of phase II for 7 days. The finding that the concentration of compound $\mathbf{3}$ needed to obtain optimal biological effects on erythroid precursor cells is higher than that employed on K562 cells is expected, as reported for other inducers of K562 erythroid differentiation and $\mathrm{HbF}$ production in erythroid progenitor cells. As a positive control, we used cultures treated with $\mathrm{HU}(100 \mu \mathrm{M})$, cisplatin $(50 \mu \mathrm{M})$ and mithramycin $(20 \mathrm{nM})$. To be consistent with the expected approach followed using K562 cells, the data obtained were compared with results obtained using tallimustine and distamycin.

The HPLC analysis of the cellular Hb content in the above cultures shows that $\mathrm{HbF}$ increases in cultures treated with compound 3 (Fig. 3) with respect to untreated cultures or cultures treated with distamycin. The amount of $\mathrm{HbF}$ in control cultures was $1.4 \pm 0.6 \%$. It increased to $4.8 \pm 0.9 \%$ 


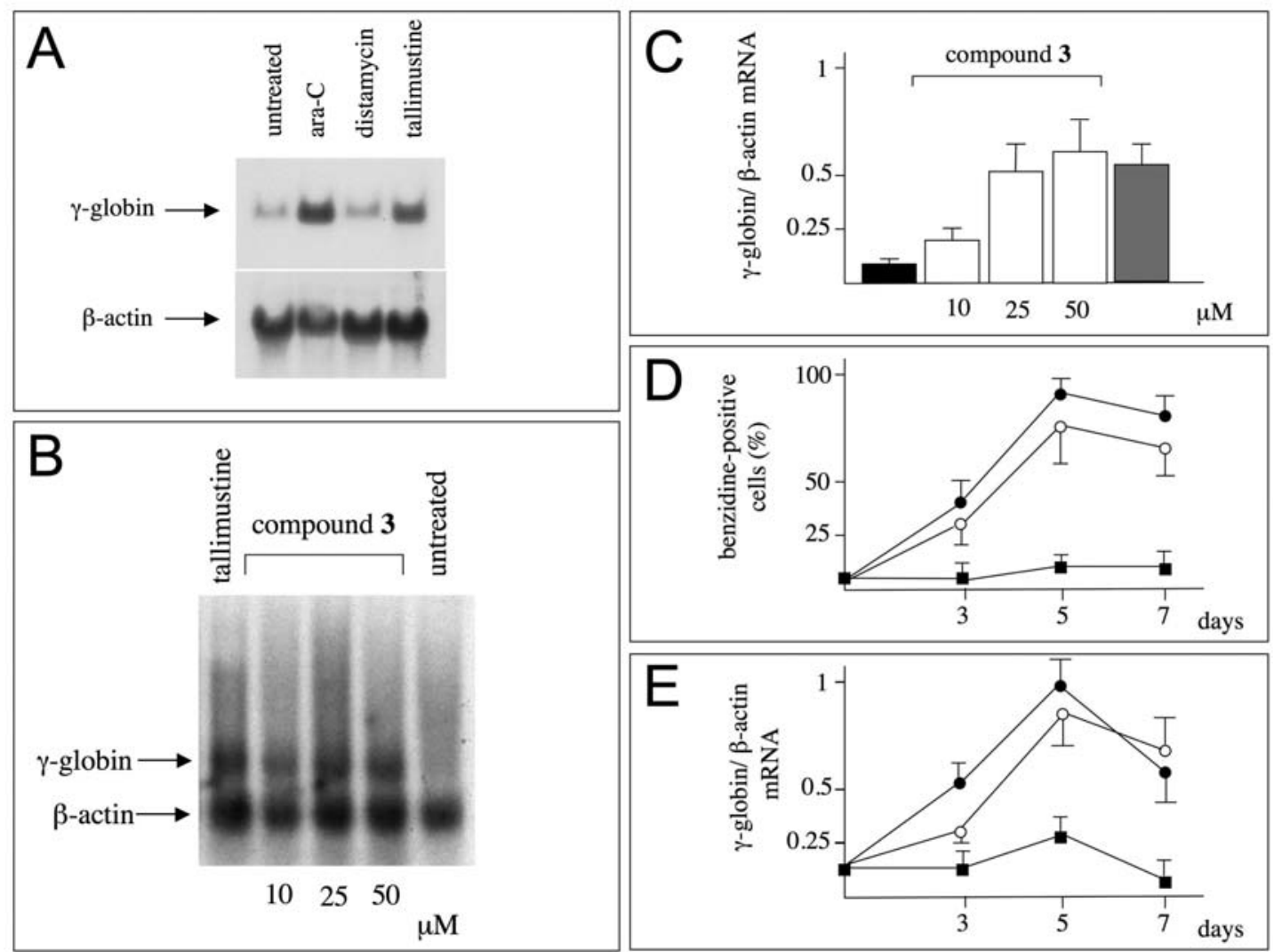

Figure 2. Northern blotting. (A-C) Total RNA was extracted from untreated K562 cells or K562 cells treated with ara-C (250 $\mu \mathrm{M})$, tallimustine (100 nM) or compound 3 at 10-50 $\mu \mathrm{M}$, as indicated. Total RNA $(10 \mu \mathrm{g})$ was loaded onto $1 \%$ agarose gel, electrophoresed, transferred to a nylon membrane (Gene Screen Plus) and hybridized using ${ }^{32} \mathrm{P}$-labelled $\gamma$-globin and $\mathrm{B}$-actin probes. The arrows in panels $\mathrm{A}$ and $\mathrm{B}$ show specific hybridizations. In panel $\mathrm{C}$ the scanning of the autoradiogram shown in panel B is reported. The black histograms on the left and on the right side represent data relative to untreated (left) and tallimustinetreated (right) cells. Data represent average \pm SD of different exposure of the autoradiographic film. (D and E) Increase of the proportion of benzidine positive cells (panel D) and $\gamma$-globin/ß-actin mRNA ratios in K562 cells after treatment for different days in the absence of inducers (solid squares) or in the presence of $10 \mathrm{nM}$ tallimustine (closed circles) or $50 \mu \mathrm{M}$ compound 3 (open circles). Data represent average \pm SD of three determinations.

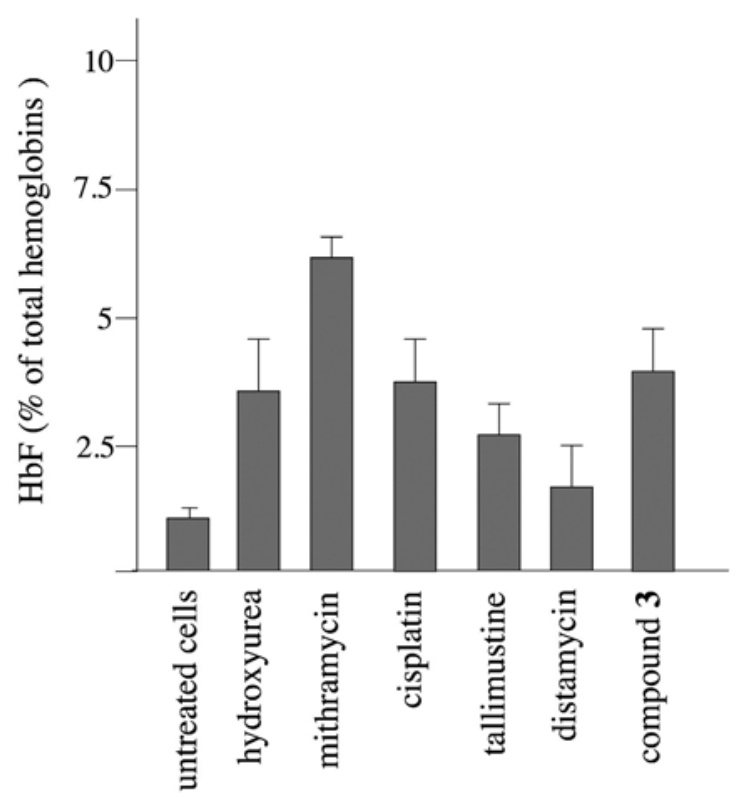

Figure 3 . HbF production by human erythroid precursor cells derived from peripheral blood and cultured in the absence of untreated cells or in the absence of hydroxyurea $(100 \mu \mathrm{M})$, mithramycin $(20 \mathrm{nM})$, cisplatin $(50 \mu \mathrm{M})$, tallimustine $(0.5 \mu \mathrm{M})$, distamycin $(0.5 \mu \mathrm{M})$ and compound $3(200 \mu \mathrm{M})$, as indicated. The concentrations of the $\mathrm{HbF}$ inducers employed were as previously published (9-11). Data represent \% of $\mathrm{HbF}$ (average $\pm \mathrm{SD}$ of three experiments). and $6.6 \pm 1.1 \%$ in $\mathrm{HU}$ - and mithramycin-treated cultures, respectively, $3.5 \pm 0.5 \%$ in cisplatin-treated cultures, $2.5 \pm 0.4$ in tallimustine-treated cultures and to $3.68 \pm 0.6 \%$ in cells treated with compound $\mathbf{3}$ (average \pm SD of three experiments).

\section{Discussion}

$\mathrm{HbF}$ inducers may be of great interest as a type of therapy for B-thalassemia and sickle cell anemia (1-8), since an increase of $\mathrm{HbF}$ is able to ameliorate the symptoms of these diseases. We report in this study that the epoxyethyl-distamycin hybrid (compound $\mathbf{3}$ ) is a potent inducer of erythroid differentiation of K562 cells. Differentiation was found to be associated with a sharp increase in the production of $\gamma$-globin mRNA.

The K562 cell line has been proposed as a useful in vitro model for studying the molecular mechanism(s) regulating the expression of embryonic and fetal human globin genes (30), as well as for screening for potential new differentiationinducing compounds $(9,12,13)$. This cell line, which was isolated and characterized in 1975 by Lozzio et al from a patient with chronic myelogenous leukemia in blast crisis, exhibits a low proportion of $\mathrm{Hb}$-synthesizing cells under standard culture conditions, but is capable of undergoing erythroid differentiation when treated with a variety of compounds including hemin (30), cytosine arabinoside (ara-C) 
(12), 5-azacytidine (20), chromomycin and mithramycin (12), tallimustine $(10,14)$, cisplatin and cisplatin analogs $(13)$. Following the erythroid induction of K562 cells, Hb Portland $\left(\xi_{2} \gamma_{2}\right)$ and Hb Gower $1\left(\xi_{2} \varepsilon_{2}\right)$ accumulate, due to an increase in the expression of human $\xi-, \varepsilon$ - and $\gamma$-globin genes (20). In vitro studies demonstrated that known inducers of erythroid differentiation in K562 cells such as HU, butyrates and 5azacytidine, are also capable of inducing $\mathrm{HbF}$ production when administered individually or in combination with normal erythroid cells (1). Butyric acid, HU and 5-azacytidine have been the subject of studies on the treatment of $\beta$-thalassemia patients $(2,3,31,32)$.

Another important conclusion of this study is related to the evaluation of the effects of compound $\mathbf{3}$ on the production of $\mathrm{HbF}$ in human erythroid precursors grown in the two-stage liquid culture system. We demonstrated that compound $\mathbf{3}$ stimulates an increase of $\mathrm{HbF}$ production, which is similar to that obtained by $\mathrm{HU}$, a potent inducer of $\mathrm{HbF}$ production in vitro and in vivo $(1,33,34)$. The results presented herein may have a practical impact, since it is well known that an increase in $\mathrm{HbF}$ production ameliorates the clinical status of patients with $B$-thalassemia and sickle cell anemia $(4,5,7)$.

Further experiments employing quantitative RT-PCR analysis are necessary to determine whether $\beta$ - and $\alpha$-globin gene expression is modified. This issue is critical in order to verify the potential interest of the molecules studied herein the field of experimental therapy of a highly heterogeneous group of hematological pathologies such as those comprising of $\beta^{\circ}$-thalassemia, $\beta^{+}$-thalassemia and sickle cell anemia. In all cases, an induction of the $\alpha$-globin gene should be avoided $(35,36)$, as only in a few cases would the increase of $\beta$-globin mRNA accumulation be beneficial (36). In conclusion, the identification of novel $\mathrm{HbF}$ inducers is of relevance as hydroxyurea is toxic and long-term treatment may lead to unwanted side effects (34), and that increasing evidence clearly shows that several $ß$-thalassemia patients are nonresponsive to hydroxyurea treatment (37).

\section{Acknowledgements}

We wish to thank Pharmacia \& Upjohn and the Ministero Università e Ricerca Scientifica (MURST) (60\%) for generous financial support of this work. R.G. is granted by Associazione Italiana Ricerca sul Cancro (AIRC), Fondazione Cariparo (Cassa di Risparmio di Padova e Rovigo), Associazione Veneta per la Lotta alla Talassemia, Rovigo, Italy (AVLT), Telethon (grant GGP07257) and the STAMINA Project. We thank the EU Project ITHANET (eInfrasctructure for Thalassemia Research Network) for support. M.L. was supported by a fellowship from AVLT and from 'Associazione per la Lotta alla Talassemia di Ferrara, Ferrara, Italy'. Partial support from the Universities of Pisa and Ferrara is also acknowledged.

\section{References}

1. Fibach E, Premakala P, Rodgers GP and Samid D: Enhanced fetal hemoglobin production by phenylacetate and 4-phenylbutyrate in erythroid precursors derived from normal donors and patients with sickle cell anemia and $\beta$-thalassemia. Blood 82 2203-2209, 1993.
2. Perrine SP, Ginder GD, Faller DV, Dover GH, Ikuta T, Witkowska HE, Cai SP, Vichinsky EP and Olivieri NF: A shortterm trial of butyrate to stimulate fetal-globin gene expression in the beta-globin disorders. N Engl J Med 328: 81-86, 1993.

3. Gambari R and Fibach E: Medicinal chemistry of fetal hemoglobin inducers for treatment of beta-thalassemia. Curr Med Chem 14: 199-212, 2007.

4. Rochette J, Craig JE and Thein SL: Fetal hemoglobin levels in adult. Blood Rev 8: 213-224, 1994.

5. Rodgers GP and Rachmilewitz EA: Novel treatment options in the severe B-globin disorder. Br J Haematol 91: 263-268, 1995.

6. Bianchi N, Zuccato C, Lampronti I, Borgatti M and Gambari R: Fetal hemoglobin inducers from the natural world: a novel approach for identification of drugs for the treatment of $B$ thalassemia and sickle-cell anemia. Evidence-based alternative and complementary medicine doi:10.1093/ecam/nem139, 2007.

7. Olivieri NF, Rees DC, Ginder GD, Thein SL, Waye JS, Chang L, Brittenham GM and Weatherall DJ: Elimination of transfusion through induction of fetal hemoglobin synthesis in Cooley's anemia. Ann NY Acad Sci 850: 100-109, 1998.

8. Swank RA and Stomatoyannopoulos G: Fetal gene reactivation. Curr Opin Genet Dev 8: 366-370, 1998.

9. Fibach E, Bianchi N, Borgatti M, Prus E and Gambari R: Mithramycin induces fetal hemoglobin production in normal and thalassemic human erythroid precursor cells. Blood 102: 1276-1281, 2003

10. Chiarabelli C, Bianchi N, Borgatti M, Prus E, Fibach E and Gambari R: Induction of $\gamma$-globin gene expression by tallimustine analogs in human erythroid cells. Haematologica 88: 826-827, 2003.

11. Lampronti I, Bianchi N, Borgatti M, Fibach E, Prus E and Gambari R: Accumulation of $\gamma$-globin mRNA in human erythroid cells treated with angelicin. Eur J Haematol 71: 189-195, 2003.

12. Viola G, Vedaldi D, Dall'Acqua F, Fortunato E, Basso G, Bianchi N, Zuccato C, Borgatti M, Lampronti I and Gambari R: Induction of gamma-globin mRNA, erythroid differentiation and apoptosis in UVA-irradiated human erythroid cells in the presence of furocumarin derivatives. Biochem Pharmacol 75: 810-825, 2008

13. Bianchi N, Ongaro F, Chiarabelli C, Gualandi L, Mischiati C, Bergamini $\mathrm{P}$ and Gambari R: Induction of erythroid differentiation of human K562 cells by cisplatin analogs. Biochem Pharmacol 60: 31-40, 2000.

14. Bianchi N, Chiarabelli C, Borgatti M, Mischiati C, Fibach E and Gambari R: Accumulation of gamma-globin mRNA and induction of erythroid differentiation after treatment of human leukemic K562 cells with tallimustine. Br J Haematol 113: 951-961, 2001.

15. Cozzi P, Beria I, Caldarelli M, Geroni C, Mongelli N and Pennella G: Cytotoxic alpha-bromoacrylic derivatives of distamycin analogues modified at the amidino moiety. Bioorg Med Chem Lett 10: 1273-1276, 2000.

16. Cozzi P and Mongelli N: Cytotoxics derived from distamycin A and congeners. Curr Pharm Des 4: 181-201, 1998.

17. Baraldi PG, Beria I, Cozzi P, et al: Cinnamoyl nitrogen mustard derivatives of pyrazole analogues of tallimustine modified at the amidino moiety: design, synthesis, molecular modeling and antitumor activity studies. Bioorg Med Chem 12: 3911-3921, 2004.

18. Baraldi PG, Cacciari B, Guiotto A, Romagnoli R, Zaid AN and Spalluto G: Heterocyclic analogues of DNA minor groove alkylating agents. Curr Pharm Des 4: 249-276, 1998.

19. Lozzio BB and Lozzio CB: Properties of the K562 cell line derived from a patient with chronic myeloid leucemia. Int J Cancer 19: 136-138, 1977.

20. Gambari R, del Senno L, Barbieri R, Viola L, Tripodi M, Raschella G and Fantoni A: Human leukemia K-562 cells: induction of erythroid differentiation by 5 -azacytidine. Cell Differ 14: 87-97, 1984

21. Fibach E, Manor D, Oppenheim A and Rachmilewitz EA: Proliferation and maturation of human erythroid progenitors in liquid culture. Blood 73: 100-103, 1989.

22. Fibach E: The use of cell culture procedures for studying fetal hemoglobin stimulating drugs. Minerva Biotechnol 15: 129-136, 2003.

23. McDonagh KT, Dover GJ, Donahue RE, Nathan DG, Agricola B, Byrne $\mathrm{E}$ and Nienhuis AW: Hydroxyurea-induced $\mathrm{HbF}$ production in anemic primates: augmentation by erythropoietin, hematopoietic growth factors, and sodium butyrate. Exp Hematol 20: 1156-1164, 1992 
24. Preisler HD and Giladi M: Differentiation of erythroleukemic cells in vitro: irreversible induction by dimethyl sulfoxide (DMSO). J Cell Physiol 85: 537-546, 1975.

25. Sambrook J, Fritsch EF and Maniatis T: Extraction, purification and analysis of messenger RNA from eukaryotic cells. In: Molecular Cloning: A Laboratory Manual. 2nd edition, Cold Spring Harbor, New York, pp7.43-7.45, 1989.

26. Wilson JT, Wilson LB, deRiel JK, Villa-komaroff L, Efstratiadis A, Forget BG and Weissman SM: Insertion of syntetic copies of human globin genes into bacterial plasmids. Nucleic Acids Res 5: 563-581, 1978

27. Borinaga AM, Millar BC, Bell JB, Joffe JK, Millar JL, Gooding R, Riches $\mathrm{P}$ and McElwain TJ: Interleukin- 6 is a cofactor for the growth of myeloid cells from human bone marrow aspirates but does not affect the clonogenicity of myeloma cells in vitro. Br J Haematol 76: 476-483, 1990.

28. Arcamone F, Penco S, Orezzi PG, Nicolella V and Pirelli A: Structure and synthesis of distamycin A. Nature 203: 1064-1065, 1964

29. Romagnoli FR, Baraldi PG, Pavani MG, Fruttarolo F, Preti D, Bovero A, Tabrizi MA, Bianchi N and Gambari R: Design, synthesis and growth inhibition activity of bis-epoxyethyl derivatives of stallimycin modified on the amicino moiety. Med Chem Res 13: 282-296, 2004.
30. Rutherford TR, Clegg JB and Weatherall DJ: K562 human leukaemic cells synthesise embryonic haemoglobin in response to haemin. Nature 280: 164-165, 1979.

31. Lowrey $\mathrm{CH}$ and Nienhuis AW: Brief report: treatment with azacitidine of patients with end-stage beta-thalassemia. N Engl J Med 329: 845-848, 1993.

32. Sher GD, Ginder GD, Little J, Yang S, Dover GJ and Olivieri NF: Extended therapy with intravenous arginine butyrate in patients with beta-hemoglobinopathies. N Engl J Med 332: 1606-1610, 1995.

33. Saxon BR, Waye JS and Olivieri NF: Increase in hemoglobin concentration during therapy with hydroxyurea in Cooley's anemia. Ann NY Acad Sci 850: 459-460, 1998.

34. Lavelle D, Molokie R, Ducksworth J and DeSimone J: Effects of hydroxurea, stem cell factor, and erythropoietin in combination on fetal hemoglobin in the baboon. Exp Hematol 29: 156-162, 2001.

35. Bianchi N, Borgatti $M$ and Gambari: Gene silencing in thalassemia. Minerva Biotechnol 20: 51-55, 2008

36. Bank A: Understanding globin regulation in $\beta$-thalassemia: it's as simple as $\alpha, \beta, \gamma, \delta$. J Clin Inv 115: 1470-1473, 2005

37. Watanapokasin R, Sanmund D, Winichagoon P, Muta K and Fucharoen S: Hydroxyurea responses and fetal hemoglobin induction in beta-thalassemia/HbE patients' peripheral blood erythroid cell culture. Ann Hematol 85: 164-169, 2006. 